\title{
Dois poemas de Bukowski em tradução
}

Sofia Lopes

Resumo: Estas são traduções dos poemas "an almost made up poem" e "eulogy to a hell of a dame", de Charles Bukowski, publicados, respectivamente, em 1977 e 1984, nos livros "Love is a Dog from Hell" e "War All the Time". Ambas as traduções buscam preservar as escolhas estilísticas originais sempre que possível.

Palavras-chave: Charles Bukowski; poesia; tradução.

\begin{abstract}
These are translations of the poems "an almost made up poem" and "eulogy to a hell of a dame", by Charles Bukowski, published in 1977 and 1984, respectively, in the books "Love is a Dog from Hell" and "War All the Time". Both translations seek to preserve the original stylistic choices whenever possible.
\end{abstract}

Keywords: Charles Bukowski; poetry; translation.

Traduzir os poemas de Bukowski é uma experiência única, mesmo para um tradutor que possua experiência prévia com a tradução poética. O verso livre, estilo empregado por Bukowski, confere certa liberdade criativa ao autor, que não se encontra preso a quaisquer limitações relativas à rima ou métrica.

Além disso, outras características dignas de nota sobre a escrita do autor são a pontuação original (ou a falta dela, em alguns casos) e a ausência de letras maiúsculas. Estes dois aspectos foram mantidos nesta tradução, como forma de preservar o efeito estilístico original.

Um dos principais desafios ao se traduzir Bukowski é reproduzir de forma fiel o tom do autor, cujas obras possuem caráter bastante autêntico e transgressor. A linguagem coloquial de Bukowski e seu interesse por temas comumente per- 
cebidos como vulgares ou banais são os traços mais característicos de sua obra. Ademais, suas escolhas linguísticas e temáticas se tornaram alguns dos principais fatores que propiciaram a difusão de sua obra; afinal, são fontes de identificação entre leitor e autor, que propiciam que os leitores vislumbrem aspectos da realidade bruta, retratados pela literatura.

Em uma publicação de 2005 para a revista The New Yorker, o poeta e crítico Adam Kirsch escreveu sobre a "poesia de Bukowski, que é simultaneamente misantrópica e afável, agressivamente vulgar e clandestinamente sensível. [...] Esta espécie de grosseria é um dos grandes atrativos de Bukowski. Sua vida, ao menos da forma como é descrita em seus poemas, é a fantasia de um garoto adolescente sobre a vida adulta." $\mathrm{O}$ apelo de Bukowski está em sua maestria ao combinar a sutileza do poeta com a brutalidade suja do realismo. É este o efeito que estas traduções buscam atingir: o equilíbrio entre o obsceno e o frágil, que retrata a humanidade de forma única e crua.

\section{Comentários sobre a tradução}

Em relação aos desafios intrínsecos à tradução da poesia de Bukowski, um exemplo digno de nota é o título do segundo poema, "eulogy to a hell of a dame". Além da linguagem informal, este título apresenta uma provocação semântica ao aludir a duas possíveis formas de interpretação do termo "hell". A expressão "one hell of" é coloquialmente usada de forma positiva como um intensificador; no contexto do poema, por exemplo, o trecho "one hell of a dame" poderia soar como "uma dama extraordinária", ou "uma dama e tanto".

Outra tradução possível seria "uma dama dos infernos". Esta tradução, no entanto, não contemplaria totalmente o sentido evocado pela expressão original, uma vez que a expressão "dos infernos" não possui conotação positiva na língua portuguesa. A escolha final, "elogio a uma puta dama", é uma tentativa de evocar os dois aspectos do título original, ao adotar a palavra "puta" como um substituto capaz de abarcar tanto o sentido figurativo positivo quanto a conotação negativa atribuída ao termo “bell”. Esta decisão também leva em consideração a coloquialidade característica do autor.

1 Tradução nossa. No original: "Bukowski's poetry, which is at once misanthropic and comradely, aggressively vulgar and clandestinely sensitive. [...] That kind of grossness is a large part of Bukowski's appeal. His own life, as it appears in the poems, at least, is a teen-age boy's fantasy of adulthood." 
Outro exemplo passível de nota, presente em "an almost made up poem”, é o trecho "her, print her, she's mad but she's/magic. there's no lie in her fire". Estes versos fazem referência direta à oralidade, à linguagem falada em oposição à escrita. A coloquialidade é expressa pelas liberdades estruturais tomadas pelo autor, como o início irregular do período quanto pelas e a ausência de letras maiúsculas. Esta informalidade faz com que estes versos sejam dignos de ponderação, especialmente pelo trecho "publish her". Caso o texto traduzido adotasse linguagem formal, estas palavras poderiam ser traduzidas como "publiquem-na". No entanto, o tom de Bukowski foi o que guiou a decisão final de adotar a tradução "publiquem ela", para garantir que este trecho se mantivesse coerente com a linguagem do restante do poema.

Além das idiossincrasias estilísticas do autor, traduzir Bukowski pode ser desafiador também pelas diferenças estruturais entre as línguas inglesa e portuguesa. Um exemplo claro deste fato pode ser encontrado em "eulogy to a hell of a dame", nos versos "you've been dead/28 years/yet I remember you/better than any of/ the rest". Neste trecho, o autor compara a dama que intitula o poema às demais pessoas que conheceu ao longo de sua vida. No entanto, não há informações específicas acerca de quem Bukowski compara a Jane, a dama em questão não há, especialmente, qualquer menção explícita ao gênero dos indivíduos mencionados. Esta ambiguidade, embora comum na língua inglesa, pode gerar certa dificuldade no processo de tradução para o português. A tradução aqui apresentada ("você morreu há 28 anos/mas me lembro de você/melhor do que de/qualquer outra") leva em consideração o tom do poema, que soa como um lamento saudoso de um amante, para concluir que os versos de Bukowski se referem às mulheres com quem ele esteve e que, por sua vez, não foram tão memoráveis quanto Jane. 


\section{um poema quase inventado}

vejo você bebendo em uma fonte com minúsculas

mãos azuis, não, suas mãos não são minúsculas

são pequenas, e a fonte fica na França

onde você me escreveu aquela última carta e eu respondi e nunca mais ouvi

notícias suas. você escrevia poemas insanos sobre

ANJOS E DEUS, tudo em letras maiúsculas, e você conhecia artistas famosos e muitos deles

eram seus amantes, e eu escrevi de volta, tudo bem,

vá em frente, entre na vida deles, não tenho ciúmes

porque nunca nos encontramos. estivemos próximos uma vez em

Nova Orleans, a meio quarteirão, mas nunca nos encontramos, nunca

nos tocamos. então você se foi com os famosos e escreveu

sobre os famosos e, é claro, o que você descobriu

é que os famosos se importam com

sua fama; não com a linda moça na cama com eles, que lhes dá o que querem, e depois acorda

pela manhã para escrever poemas em letras maiúsculas sobre ANJOS E DEUS. sabemos que Deus está morto, eles nos disseram, mas ao ouvir você eu não tive certeza. talvez

fossem as letras maiúsculas. você foi uma das melhores poetisas e eu disse aos editores "ela, publiquem ela, ela é louca mas é

mágica. não há mentira em seu fogo.” eu amei você

como um homem ama uma mulher que nunca toca, apenas

escreve para ela, guarda pequenas fotos dela. eu teria

te amado mais se tivesse me sentado em um pequeno quarto enrolando um

cigarro e ouvido você mijar no banheiro,

mas isso não aconteceu. suas cartas ficaram mais tristes.

seus amantes te traíram. garota, eu escrevi, todos

os amantes traem. não ajudou. você disse que

tinha um banco de chorar e ele ficava perto de uma ponte e

a ponte passava sobre um rio e você se sentava no banco

de chorar todas as noites e chorava pelos amantes que tinham

te ferido e esquecido. eu escrevi de volta mas

nunca mais ouvi notícias. um amigo me escreveu sobre seu suicídio

3 ou 4 meses depois dele acontecer. se eu tivesse te conhecido eu provavelmente teria sido injusto com você ou você comigo. foi melhor assim. 


\section{an almost made up poem}

I see you drinking at a fountain with tiny blue hands, no, your hands are not tiny they are small, and the fountain is in France where you wrote me that last letter and I answered and never heard from you again. you used to write insane poems about ANGELS AND GOD, all in upper case, and you knew famous artists and most of them were your lovers, and I wrote back, it's all right, go ahead, enter their lives, I'm not jealous because we've never met. we got close once in New Orleans, one half block, but never met, never touched. so you went with the famous and wrote about the famous, and, of course, what you found out is that the famous are worried about their fame - not the beautiful young girl in bed with them, who gives them that, and then awakens in the morning to write upper case poems about ANGELS AND GOD. we know God is dead, they've told us, but listening to you I wasn't sure. maybe it was the upper case. you were one of the best female poets and I told the publishers, editors, " her, print her, she's mad but she's magic. there's no lie in her fire." I loved you like a man loves a woman he never touches, only writes to, keeps little photographs of. I would have loved you more if I had sat in a small room rolling a cigarette and listened to you piss in the bathroom, but that didn't happen. your letters got sadder. your lovers betrayed you. kid, I wrote back, all lovers betray. it didn't help. you said you had a crying bench and it was by a bridge and the bridge was over a river and you sat on the crying bench every night and wept for the lovers who had hurt and forgotten you. I wrote back but never heard again. a friend wrote me of your suicide 3 or 4 months after it happened. if I had met you I would probably have been unfair to you or you to me. it was best like this. 


\section{tributo a uma puta dama}

alguns cachorros que dormem à noite devem sonhar com ossos

e eu me lembro dos seus ossos na carne

e ainda melhor naquele vestido verde escuro e naqueles sapatos brilhantes

$$
\text { e pretos, }
$$

você sempre xingava quando bebia, seu cabelo se soltando e você queria explodir para fora do que estava te prendendo:

memórias podres de um passado

podre, e você finalmente

escapou morrendo,

me deixando com o presente podre;

você morreu há 28 anos

mas me lembro de você melhor do que de qualquer outra;

você era a única que entendia

a futilidade dos mecanismos da vida;

todos as outras só estavam aborrecidas com segmentos triviais, reclamavam

insensatamente sobre coisas insensatas; Jane, você foi morta por

saber demais. faço um brinde aos seus ossos com os quais este cachorro ainda sonha. 


\section{eulogy to a hell of a dame}

some dogs who sleep at night

must dream of bones

and I remember your bones

in flesh

and best

in that dark green dress

and those high-heeled bright

black shoes,

you always cursed when you drank,

your hair coming down you

wanted to explode out of

what was holding you:

rotten memories of a

rotten

past, and

you finally got

out

by dying,

leaving me with the

rotten

present;

you've been dead

28 years

yet I remember you

better than any of

the rest;

you were the only one

who understood

the futility of the

arrangement of

life;

all the others were only 


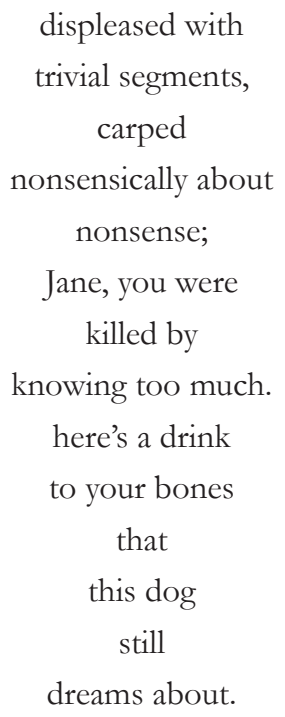

\section{Referências bibliográficas}

BUKOWSKI, Charles. Love is a Dog from Hell. Santa Barbara: Black Sparrow Press, 1977. BUKOWSKI, Charles. War All the Time. Santa Barbara: Black Sparrow Press, 1984.

KIRSCH, A. The Transgressive Thrills of Charles Bukowski. The New Yorker, 2005. Disponível em: https://www.newyorker.com/magazine/2005/03/14/smashed/amp. Acesso em: 2 out. 2020 . 